\title{
Analysis of ERP Implementation in Perum BULOG with Extended TAM 3 Approach
}

\author{
Muhammad Ainul Fahmi ${ }^{1}$, Udisubakti Ciptomulyono ${ }^{2}$ and Jani Rahardjo ${ }^{3}$ \\ ${ }^{1}$ Department of Technology Management, Institut Teknologi Sepuluh Nopember, Surabaya, Indonesia. \\ ${ }^{2}$ Department of Industrial Engineering, Institut Teknologi Sepuluh Nopember, \\ Surabaya, Indonesia. \\ ${ }^{3}$ Department of Industrial Engineering, Petra Christian university, Surabaya, Indonesia \\ e-mail: ainulfahmi.af25@gmail.com
}

\begin{abstract}
Several previous studies explained that the implementation of an integrated information system needed to be realized at Perum BULOG because the old system has not been integrated. This was also realized by the management of Perum BULOG by carrying out one of its long-term plans, namely carrying out the implementation of ERP system in 2020. On the other hand, ERP is a complex system because ERP systems often adds more difficulties to the implementation process. Therefore, it is necessary to conduct research on the analysis of ERP implementation at Perum BULOG to see how ERP users will accept this technology using the extended TAM 3 approach. Outer Model and Inner Model are used to test and analyze data from research instruments using the SMART PLS 3.0. Based on the research findings, it can be seen from 12 research hypotheses, 9 research hypotheses were accepted and 3 were rejected. It is known that perceived usefulness is found only factor in system- technology ERP and perceived ease of use which have a positive and significant correlation. Meanwhile, the perceived ease of use factor was found only the organization process characteristic and system-technology ERP factor that had a positive and significant correlation. Furthermore, the attitude factor of ERP user is influenced by the perceived usefulness and perceived ease of use. Where the ERP user attitude factor is able to encourage behavioral intention and have implication for use and user satisfaction.
\end{abstract}

Keywords-ERP System, ERP Implementation Phase, TAM, Extended TAM 3.

\section{INTRODUCTION}

$\mathrm{P}$ ERUM BULOG has the aim of participating in implementing Government programs in the field of food logistics [1]. Meanwhile, Fitrianto [2] and Fazizah, et al. [3] mentioned in their researchs that the technology used previously in Perum BULOG, namely SIAB (BULOG Accounting Information System) and (Logistic Information System), has not been integrated so that users are not satisfied with the system timeline. Furthermore, the business environment has changed significantly so that it is considered necessary to develop information technology (IT) [1] of ERP. Perum BULOG has begun the adaptation decision phase of system ERP in 2018, then in 2019 it has done acquisition phase and subsequently has run implementation phase in 2020. Nevertheless, ERP is complex system and many researchers have observed that usability is one of the reasons for ERP system failure. So that, we need method which it could analysis the implementation of system ERP in Perum BULOG. In this area, TAM proved to be the most efficient model to study adoption in information systems because TAM has become well-established as a robust and predictive [4] [5] and therefore numerous information systems researchers apply this method to study ERP acceptance as well.

TAM introduced by Fred D. Davis, Jr. in 1986 in his doctoral dissertation at MIT was an adaptation of TRA specially designed to predict and explain user behavior and IT usage. Furthermore, Davis et al. in 1989 [6] established TAM 1 in their study which is perceived usefulness (PU) and perceived ease of use (PEOU) in TAM positively affect a person's attitude towards the use of new technology (AT), which in turn will affect behavioral intentions (BI) in users. Finally, the behavioral intention positively influences actual use (USE). Moreover, in 2000 Venkatesh and Davis in their research [4] propose an extension of the TAM model known as TAM 2 by identifying common determinants of perceived usefulness (PU). Then, Venkatesh in 2008 [7] try to combine the TAM 2 model and the determinant model of perceived ease of use to develop an integrated model known as TAM 3. Finally, Calisir, et al., in 2009 in their study [8] mentioned that the construction of TAM 3 needs to be extended to include additional factors. The target technology, primary users and context must be taken into account when selecting additional factors which we call it as extended TAM 3. So that, the aim of this research is to conduct studies and analysis of ERP implementation in Perum BULOG to find out how ERP users will accept the technology using the extended TAM 3 method (Technology Acceptance Model 3).

\section{METHOD}

A. Conceptual Model of Research (Figure 1)

1. 6 main determinants (PEOU, PU, AT, BI, Use, USS).

2. 12 external factors (PI, CA, CSE, IB, SP, UM, SYSQ, QI, SI, TRAI, CS, COM).

3. 3 groups of external factors (PCIL, STC, OPC/ P support).

\section{B. Conceptual Model of Research}

12 Hypotheses 


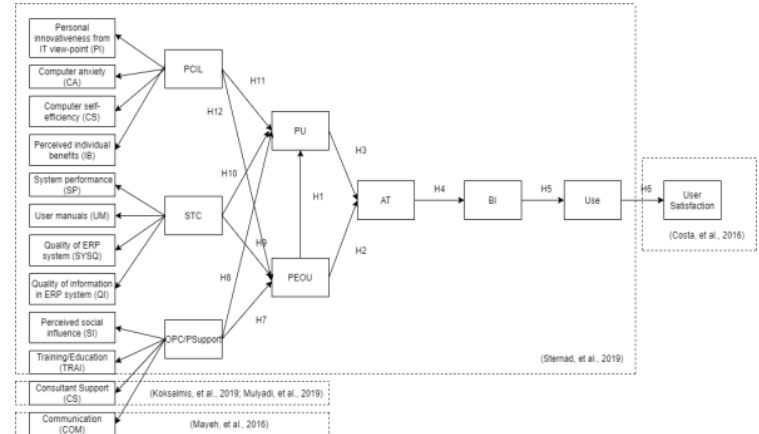

Figure 1. Conceptual Model of research

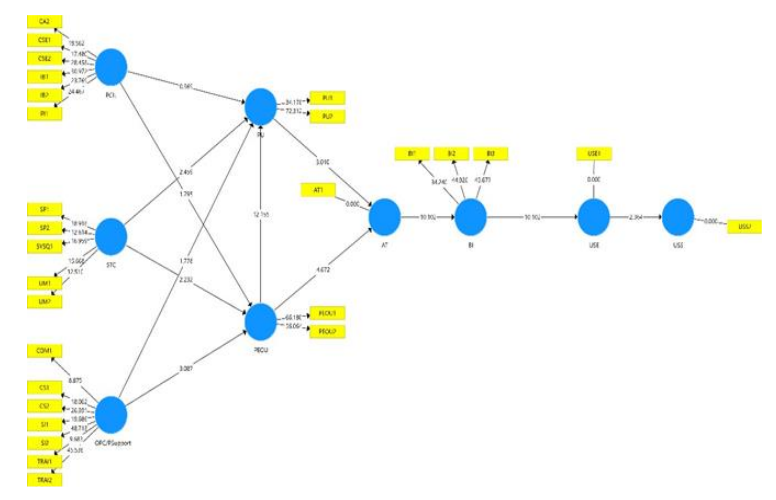

Figure 2. Result of inner model.

\section{Determination of Operational Variables}

9 factors of first order (PCIL, STC, OPC / Psupport PEOU, PU, AT, BI, Use, and USS)

\section{E. Designing a Questionnaire}

Using google form, measured by 5 Likert scale consisting of 39 question indicators

\section{F. Questionnaire Data Collection}

366 samples from 4200 population of employees of Perum BULOG throughout Indonesia

G. Data Processing Methods

1) Outer Model Test

2) Inner Model Test

H. Test Tool

Smart PLS 3.0

\section{RESULTS AND DISCUSSION}

\section{A. Outer Model Result}

1) Convergent Validity

1. All of loading factors are greater than 0.6 except PI1, SYSQ2, Q1, Q2, COM2, AT3, AT4, dan USS1 factor

2. 9 factors of first order (PCIL, STC, OPC/Psupport PEOU, PU, AT, BI, Use, and USS) have average variance extracted (AVE) greater than 0.5

\section{2) Discriminant Validity}

Cross loadings of BI4 and CA1 is not valid because lower than other constructs.

\section{3) Reliability Test}

All of Cronbach' s alpha are greater than 0.7 except AT so the indicator AT2 in cross loading must be eliminated to gain valid Cronbach alpha

\section{B. Inner Model Result \\ 1) $R$-Square}

AT, BI, PEOU and USE can be explained by PCIL, STC, OPC / PSupport by $20 \%$. PU is $50 \%$ and USS only $2 \%$ are explained by exogenous variables, while the rest is explained by other exogenous variables outside of this study [9].

\section{2) Predictive Relevance/Blindfolding}

All predictive relevance $\left(\mathrm{Q}^{2}\right)$ values are more than 0 so it can be concluded that the model has relevant predictive value [10].

\section{3) Bootstrapping/T-Statistic}

Only $\mathrm{H} 8, \mathrm{H} 11$ and $\mathrm{H} 12$ are rejected because the TStatistic value is less than 1.96 [10].

4) Bootstrapping/T-Statistic (Figure 2)

Only PCIL factor has negative influence on PU factor (H11) [11].

\section{Discussion}

1. Based on the research findings, it can be seen from 12 research hypotheses, 9 research hypotheses were accepted and 3 were rejected.

2. It is known that perceived usefulness is found only factor in system-technology ERP (STC) and perceived ease of use (PEOU) which have a positive and significant correlation.

3. Meanwhile, the perceived ease of use (PU) factor was found only the organization process characteristic (OPC/Psupport) and systemtechnology ERP (STC) factor that had a positive and significant correlation.

4. PCIL has no effect on PU and PEOU because in the industrial era 4.0, everyone already knew a lot about personal characteristics and information literacy [5]. Meanwhile, OPC/PSupport has no effect on PU because this factor is more aimed at user convenience rather than providing usability. Furthermore, the attitude (AT) factor of ERP user is influenced by the perceived usefulness (PU) and perceived ease of use (PEOU). Where the ERP user attitude factor is able to encourage behavioral intention and have implication for use (USE) and user satisfaction (USS).

\section{REFERENCES}

[1] Perum BULOG, “Annual Report Perum BULOG 2018,” 2018.

[2] Y. Fitrianto, "Analisa Pemanfaatan SIAB Dalam Laporan Keuangan Pada Bulog Divre Jatim,” Diploma thesis,. STIE Perbanas, Surabaya, 2019.

[3] A. Fazizah, E. G. Sukoharsono, and K. Kertahadi, "Analisis penggunaan aplikasi sistem informasi logistik (sil) untuk perencanaan, pelaporan dan pengendalian berbasis web dan pengaruhnya terhada kinerja dan kepuasan pengguna (studi pada: pengguna aplikasi sil perum bulog divisi regional jawa timur)," Profit: Jurnal Administrasi Bisnis, vol. 10, no. 2, pp. 11-20, 2016. DOI 10.21776/ub.profit.2016.010.02.2 
The $2^{\text {nd }}$ International Conference on Global Development - ICODEV

December $5^{\text {th }}, 2020$, Online Conference

[4] V. Venkatesh and F. D. Davis, " A theoretical extension of the technology acceptance model: four longitudinal field studies,' Management Science, vol. 46, no.2, 2000, pp. 186-205.

[5] S. Sternad, R. Picek, S. Bobek, I. S. Klancnik, and P. Tominc, "Technology acceptance model based study of students' attitudes toward use of enterprise resourse planning solutions," Journal Information and Organizational Sciences, vol.43, no.1, pp. 49-71. 2019

[6] F. D. Davis, R. P. Bagozzi, and P. R. Warshaw, "User acceptance of computer technology: a comparison of two theoretical models," Management Science, vol. 35, no. 8, pp. 982-1003. 1989

[7] V. Venkatesh and H. Bala, "Technology acceptance model 3 and a research agenda on interventions," Decision Sciences, vol.39, no.2, pp. 273-315, 2008.

[8] F. Calisir, C. A. Gumussoy and A. Bayram, "Predicting the behavioural intention to use enterprise resource planning systems - an exploratory extension of the technology acceptance model," Management Research News, vol. 32, no.7, 597-613, 2009.

[9] I. Ghozali, Aplikasi Analisis Multivariate dengan Program IBM SPSS 23. Semarang: Badan Penerbit Universitas Diponegoro. 2015

[10]J. F. Hair, M. Sarstedt, and C. M. Ringle, "Partial least squares structural equation modeling," Handbook of Market Research, vol. 15, no. 1, pp 1-40, 2017.

[11]J. F. Hair, M. Sarstedt, L. Hopkins, and V. G. Kuppelwieser, "Partial least squares structural equation modeling (pls-sem): an emerging tool in business research," European Business Review, vol. 26, no. 2, pp. 106-121, 2014. 